\title{
Ethnoarchaeology and Undefined Investigations
}

Eric Laurier \& Chris Philo

University of Glasgow

June 2002

Paper in preparation for Environment and Planning A - Theme Issue 'What Next'.

Acknowledgements : Eric Laurier has been supported by an Urban Studies Fellowship and ESRC grant (R000239797) during the writing of this article. The staff at Offshore for providing us with a café, some sofas and 'coffee next'. 


\section{'What next?'}

We hear a question. Anything could happen. A world filled with promise, terror, boredom, love, work (so much work) and sometimes surprises. We might go to the park. We might have to fill in an evaluation form. We might find ourselves daydreaming. We might stay silent under interrogation. We might start our journey home. We might go shopping for food for dinner. We might say we don't know. We really might not know.

For the pair, for us as a pair, fitted together, similar yet not exchangeable, like a left shoe and a right shoe, the question finds it relevance in a long standing task, to write a paper where we might finally place our conceptual equipment side-by-side. As left follows right and right follows left, in this paper we will walk through our singular and shared studies in the poetic, political and practical programmatic legacies of Michel Foucault and ethnomethodology . More particularly we will follow the faltering steps that Chris has taken in the pathways of Foucault's arguably most difficult book, L'archaeologies du savoir (tran.s The Archaeology of Knowledge (Foucault 1972) : see Philo, 1989) together with steps that Eric has more recently followed with the disparate travelling band that is ethnomethodology (Garfinkel 1967; Garfinkel \& Sacks 1970; Garfinkel \& Wieder 1992; Lynch 1993). Previously we have collaborated in examining the work of others, notably Bruno Latour (Laurier \& Philo 1999), and in the analysis of empirical materials such as the daily routines of car-based workers (Laurier \& Philo 2003). Up until now, we have refrained from too close an inspection of one another's intellectual backgrounds, resources and commitments. What sense does it make to ask the right foot what the left does next? The next step is made in the walking. Yet there is value in the kind of exercise that makes available for our investigation what the 'other' foot does, such as when we try to dance our partner's steps or kick a ball with the other foot. Our pause for inspection may hold some interest for other geographers wondering about the conceptual manoeuvres that may come to invigorate endeavour within (and beyond the discipline). We say this less because we suppose there to be some special 'answer' in conjoining Foucault's archaeology with Garfinkel's ethnomethodology - although maybe there is something novel to be said here - and more because it may be in the principle of conversations between different styles of thinking, hybridisations of topical concerns and, most of all, ways of investigating, that 'what next' will reside.

For us in the event of writing this we hear 'what next' as something we have been planning ought to happen. It means we will finally begin considering the affinities and complementarities between Foucauldian historical investigations and the studies of practical action and practical reasoning, otherwise known as ethnomethodology. Foucault's work has been enthusiastically absorbed by numerous disciplines, raising his status and influence on the humanities and social science to the degree where he is thought of in some quarters as the Karl Marx of the twentieth century. By comparison, ethnomethodology has been treated as something of a curiosity in the development of the social sciences, its practitioners pursuing 'studies' with a missionary zeal and dismissing attempts to integrate their findings, methods or conceptual clarifications into other 
programmes of social, cultural and psychological research ${ }^{\square}$ Their studies are, by their self-assessment, asymmetrically alternate to, it would seem, any other kind of project in the social sciences: ' $[\mathrm{t}]$ he following of the methodologies of one makes the other 'disappear': the methodologies are radical alternatives to each other, fundamentally disjunctive rather than being complimentary or reconcilable by means of an additive formula which juxtaposes and purportedly articulates the two' (Watson 1994; p177). With such warnings about the ethno-inquiries of Garfinkel, Sacks and others in mind, we nevertheless wish to argue in sympathy with McHoul $(1986 ; 1996)$ for the particular appropriateness of reconciling ethnomethodology with the work of Foucault. Indeed as Watson $(1994 ;$ p117) continues, 'there can certainly be no a priori objection to each and any reconciliation, as much of course depends upon the logic of the particular cases in point ' We might in fact argue that by its very popularity, Foucault's work has suffered much more than ethnomethodology from being skimmed for its 'big ideas' (i.e. panopticism in particular, see Philo 1992 where Chris complains about the only Foucault known to geographers being 'the geometer of power'.), then affiliated and all too often inappropriately added to various theoretical frameworks in the social sciences and cultural studies.

In our daily research practice, then, we find our footing in these two distinctive ways of pursuing empirically-bound investigations of classical topics of philosophy, human geography, history, sociology, critical theory and so on. By our own convenient shorthands for one another's approaches we have traded on a division between Foucault's forms of self-serious discourse in circulation and ethnomethodology's attention to common or garden spatial phenomena and talk-in-interaction. By contrasting the two each has given us purchase where the other starts to let slip, since ethnomethodology is the programme 'par excellence that has been able to generate detailed findings about concrete social situations and the forms of semiosis that produce them (and that, reflexively, they produce). On the other hand, Foucauldian discourse analysis has been superbly capable of situating discourse in terms of its general effectivity as means of producing (and being produced by forms of knowledge, power and subjectivity in their broadest historical senses' (McHoul 1996). This observation comes Alec McHoul's (McHoul 1986; McHoul 1996) illuminating remarks on the 'two quite theoretically distinct sociologies' (1986, p65) of Garfinkel and Foucault. In an exploration of the public methods for passing on the private knowledge of sexuality, McHoul considers both 'touchstones' for the two traditions, and the elements of each which are incommensurate. His ambition for his own 'semiotic investigations' is that they should be able to stretch from the 'situational', via the 'social', to the 'historical' (McHoul, 1996, p101). It is in McHoul's initial meeting of ethnomethods and discourses that the term

\footnotetext{
${ }^{1}$ If there is one substantial gain to be had from ethnomethodology meeting human geography it is that there has not been an antagonistic history in previous encounters in stark contrast to its dark status in other social sciences.

${ }^{2}$ It is highly appropriate to set Rod Watson and Alec McHoul's remarks on ethnomethodology side by side since Watson has perhaps most clearly expressed why ethnomethodology cannot straightforwardly be added to, or combined with, other approaches (Watson 1992). McHoul, at one time Watson's student and to whom Semiotic Investigations is McHoul's 'answer - for Rod - though I don't doubt he'll disagree with it' (1996, pxxii), has by contrast made a singular and nuanced argument as to the post-structural approaches to which ethnomethodology could fruitfully be aligned.
} 
'ethnogenealogy' is coined and we make no special point in calling our follow-up to his lead, 'ethnoarchaeology'. McHoul uses archaeology and genealogy interchangeably in his essay and Chris equally has argued, contra Deleuze and others, for the continuity between Foucault's archaeologies and genealogies. Indeed we remain somewhat wary of giving a name at all to 'what next' for reasons that will become clear a little later.

To follow the straightforward division of their strengths put forward by McHoul, Foucault provides a historicism which ethnomethodology lacks. From the other side, ethnomethodology localises what otherwise become grand periodisations from Foucault's histories. As Chris has emphasised from the outset (Philo 1992) to follow the examples set in Foucault's historical geographies entails the avoidance of 'total histories' in favour of what he terms 'general histories'; a disavowal of grand-theoretical simplifications, even as he is ready to provide 'big picture' historical surveys, and a preference for 'untidy' inquiries where chaos and incommensurability in the stuff of the inquiries are readily foregrounded. Whilst retaining a wariness over the theoretical ambitions of Foucauldian studies, Lynch, one of the figures in ethnomethodology alongside McHoul willing to hybridise it, if cautiously and critically, with other disciplines, this same contrast:

Foucault's descriptions nevertheless can be exemplary for ethnomethodological investigations, because they so clearly identify how material architectures, machineries, bodily techniques, and disciplinary routines make up coherent phenomenal fields. Whereas Foucault problematises the diachronic continuity of historical discourses, ethnomethodology explodes the contemporaneous landscape of language games into distinctive orders of practice, which are neither hermetically sealed from one another nor expressive of a single historical narrative. (Lynch 1993) p131

In what follows we will sketch out a basis, building on McHoul and Lynch's first steps, for ethnoarchaeologies to follow, since what we are doing here is not an exhibition of an ethnoarchaeological study. Our ambition is to fashion a series of specific hinges around which we will swing between Foucault's 'archaeology' and Garfinkel \& Sack's 'ethnomethodology' ; and we will deliberately mix up our discussions of each, avoiding setting them out in stark contrast to one another. It should be underlined that our reading of the Archaeology of Knowledge is through the lens provided by in the English edition's Preface, which was written round about the same time as 'Nietzsche, la généalogie, l'histoire' (Foucault 1971), wherein Foucault talks of the boring, grey task of historical work. At this point in Foucault's development 'archaeology' and 'genealogy' look much the same, as descriptions of a stance before history and its traces, whereas subsequently 'genealogy' begin to look more like an empirical grasp on the workings and lineages of power, though once again we would not wish to overplay a decisive split on Foucault's oeuvre.

\footnotetext{
${ }^{3}$ Ethmethodologists have always been happy to hybridise with practitioners such as the police, filmmakers, jazz players, astronomers, truckers, lawyers, builders, engineers, nurses and designers, pursuing studies grounded in the vernacular expertise of those groups which are uniquely adequate rather than general models or theories.
} 


\section{'We'll call it ethno-archaeology': formal properties and rules}

As with so many snappy titles foisted on larger intellectual projects, like 'deconstruction' or 'actor-network theory', 'ethnomethodology', while not all that snappy, since it is double dipthonged and polysyllabic, has allowed for short definitions which make something arguable and locatable in a literature of the social, cultural and historical disciplines while ignoring its rich corpora. Interviewed on the origins and meaning of the term, Garfinkel was characteristically spikey:

'I am going to tell you right now that I cannot be held responsible for what persons have come to make of ethnomethodology. Here I am talking about 'ethnomethodology', because there are now quite a number of persons who, on a day-to-day basis, are doing studies of practical activities, of common-sense knowledge, of this and that, and of practical organizational reasoning. That is what ethnomethodology is concerned with. It is an organizational study of a member's knowledge of his ordinary affairs, of her own organized enterprises, where that knowledge is treated by us as part of the same setting that it also makes orderable... one way to start this meeting would be to say, 'we've stopped using ethnomethodology. We are now going to call it "neopraxiology".' That would at least make it clear to whoever wants the term ethnomethodology, for whatever you want it for, go ahead and take it. You might as well since our studies will remain without that term. I think the term may, in fact, be a mistake. It has acquired a kind of life of its own.' (Garfinkel 1974)

Similarly, the 'archaeology of knowledge' offers a name which has tended to supplant the body of work, to be wondered about in isolation, to start generating questions about Foucault's efforts that might be seen as quite misplaced were his collection of substantive studies consulted. Also it ignores the specifity of the Archaeology of Knowledge, as a 'topical' study of how enduring knowledge is made (and archived); as such, it is not straightforwardly a window on to Foucault's methodology although there are elements that can be extracted from the Archaeology of Knowledge to stand as more programmatic claims about history and our attempts to excavate it. Rather than implying the unearthing of the foundations on which knowledge rests, Foucault's use of 'archaeology' was related to the slow removal of soil with delicate hand-tools, the trowelling, picking and brushing away of dirt, to reveal the shape of the object normally surrounded by soil. Thus it is a title that refers analogously to the investigator's practice rather than to a more metaphoric sense of digging down (we will return to this depth metaphor later when discussing 'surfaces' and 'visibility'). Various writers, Deleuze (1988) amongst them, talk about the Archaeology of Knowledge as summarising Foucault's 'archaeological' approach as taken in his inquiries up until this book; they distinguish this phase in his work from a later 'genealogical' approach hung up on the hinges of power. We would remain at best cautious about such a division in Foucault's progress and at worst see it as misleading. It can throw readers off the track in the same way that the over-emphasized switch in 
Wittgenstein's work between the Tractatus (Wittgenstein 1961 (orig.1922)) and the Philosophical Investigations (Wittgenstein 1953) all too often does (Hacker 1989; Hacker 2000).

A point of juxtaposition between ethno-inquiries and archaeologies to begin with is that Foucault attained a philosophical vantage point that rejected any commitment to naturalism or any employment of formal language systems, while ethno-inquiries are committed to naturalistic studies and are centrally concerned with formal structures of practical actions. Might this however not be quite the disjunction it appears to be? Firstly let us register the distance that separates Foucault's view of discourse from the heritage of structural linguistics and semiology that was, at one point, posited as the fundamental and fashioning tap-root of his particular project. Perry Anderson, for instance, placed Foucault beside Jacques Derrida and Jacques Lacan as structuralists or neo-structuralists still writing squarely in the space opened up by Saussure's Course in General Linguistics and as fellow antagonists of the Marxist heritage of historical materialism. A more sophisticated inquiry is erected by Alex Callinicos, who, like Anderson, was concerned to avert modern philosophical assaults on Marxism. Although he, and Megill (1985), put much more emphasis on the Nietzschean heritage in the thinking of Foucault and Deleuze, they nonetheless portray Foucault quite clearly as an heir of the revolution of language marked out by Saussure's decisive break with earlier classical doctrines of language. The claims advanced by Anderson, Callinicos and Megill certainly contain many seeds of truth, but we would still argue that the original version of structural linguistics and even the later appropriations of that vision by various French theorists evince a naturalism and formalism that is rarely seen in the pages of Foucault's many texts. Even though Foucault may no longer be taken to be a latter day Saussurean semiologist, he is still mis-characterised as searching for Discourse which is taken to be a system like 'la langue' of Saussure's langue/parole structural binary. As he locates his work in one interview:

'I am at the difference from those we call structuralists for I am not very interested in the formal possibilities offered by a system like language (la langue). Personally, I am above all haunted by the existence of discourses; by the fact that speaking has taken place as events in relation to their original situation, and that they have left behind traces which continue to exist and exercise in their very subsistence internal to history, a certain number of manifest or secret functions'.

Clearly then Foucault warns off those who would place him amongst the structuralists. $\mathrm{He}$ is signalling his concern for speaking as an event which can only be made proper sense of by placing it in its original situation. Too much weight should not be put upon 'secret' in his remark since the function of speech in its place is secret only in so much as it not immediately available to us in the way we might understand the same speech in our situation today and so it requires the careful re-articulation of the statement into the local historical conditions which made it possible. Deleuze expresses Foucault's grasp on what is hidden from view most eloquently: 
'That everything is always said in every age is perhaps Foucault's greatest historical principle: behind the curtain there is nothing to see, but it was all the more important each time to describe the curtain, or the base, since there was nothing behind it nor beneath it' (Deleuze 1988a) p54.

Where Foucault emphasises his disinterest in the formal possibilities of language, Garfinkel and Sacks (1970) are deeply interested in formal structures but indifferent to any principled distinction between professional sociological (or psychological or cultural or historical) reasoning and 'legal reasoning, conversational reasoning, divinational reasoning, psychiatric reasoning, and the rest'(Garfinkel \& Sacks 1970). So, although sharing what might be called a constructionist attitude to social activities, 'the two understand formal structures differently and in incompatible ways' (Garfinkel \& Sacks 1986; p165). From a cursory reading of the published work in conversational analysis (CA) in particular it has been easy for critics to imply that it is a formal account of just the kind that Foucault, and many other post-structuralists, would want to dispute. Both Garfinkel and Sacks were fond of tables, diagrams and unusual textual renderings of phenomena (see fig. 1) which could easily be confused with an attempt to create formal, cohort-independent models, rules or laws. However, Garfinkel, in particular, would use such diagrams to demonstrate the inescapable loss of a phenomenon by any rendering practices and to make the rendering process (the 'curtains' of scientific methodology as it were) visible. At a more conceptual level ethnomethodology collapses the semiotic binary which Saussure used, showing through frequent perspicuous examples that $l a$ langue does not exist outside of its use in parole. It follows Wittgenstein's later dismissal of the possibility that we should use ladders to climb up out of ordinary language (Wittgenstein 1980). Garfinkel and Sacks, in their (only) joint paper, argue that practices, language games, workplaces, everyday life have the very possibility of their existence, comprehensibility and analysability '(a) in that they exhibit upon analysis the properties of uniformity, reproducibility, repetitiveness, standardization, typicality and so on; (b) in that these properties are independent of particular production cohorts; (c) in that particular cohort independence is a phenomenon for members' recognition; and (d) in that the phenomenon (a), (b), and (c) are every particular cohort's practical situated accomplishment' (Garfinkel \& Sacks 1986; p166).

Hopefully it is becoming apparent that ethnomethodology develops a very odd kind of interest in formal properties which does not seek its own formal system that would liberate, democratise, correct, perfect or ironicise existing practice (contra say Habermas's (1980) search for the ideal speech situation). Sacks in his (1963) paper on sociological description critiqued the 'ironic' stance of classical sociology, for applying external standards that, as Watson puts it, is 'derived from the formal categories or procedures of science, or, worse, an idealized version of them. All too often, this results in commonsense understandings being deemed primitively deficient, superficial, misconceived, inadequate, interested, stereotypical, mystificatory - in short as an inferior, naïve or degenerate version of what is yielded by the (idealized) scientific approach' (Watson 1994; p173) . Clearly then this a situation very close to Foucault's own; disjunct from similar 'ironic' structuralist formalisations of language; it foregrounds background expectations and dispersed 'serious' techniques of ordering. On this basis we would 
argue that it would be a mistake to oppose Foucault and ethnomethodology on the basis of one's rejection of formalism and the other's apparent focus upon it.

$* * *$ insert diagram

Fig. 1 'Summoning phones' from (Garfinkel \& Wieder 1992)

Moreover, Foucault embraces a conception of rules and laws similar to that of ethnomethodology, since he clearly rejects any attempt to propose 'cross-cultural, ahistorical, abstract laws' somehow operating outside of, beyond, behind or below the concrete, dispersed details of particular historical and geographical conjunctures (Philo 1992). His feeling is instead for rules as specific, local and mutable conditions of existence - as regularities speaking across the various levels of the enunciative field which are, in a sense, both statements themselves and their specific conditions of existence. Deleuze puts it thus: 'A statement operates neither laterally nor vertically but transversally, and its rules are to be found on the same level as itself' (Deleuze 1988a) p5.When such regularities are definable (and the analyst's job is not to do the defining but to find definable regularities), then Foucault says 'for the sake of convenience we are dealing with a discursive formation ... The conditions to which the elements of this division (objects, modes of statements, concepts, thematic choices) are subjected we shall call the rules of formation. The rules of formation are conditions of existence (but also of co-existence, maintenance, modification and disappearance) in a given discursive division' (Foucault 1972, p38). By situating a statement in a discursive formation we are given the laws that govern it - the location of a statement and the rules for its location and operation are homologous. Any 'discursive formation is characterised not by principles of construction but by a dispersion of fact, since for statements, it is not a condition of possibility but a law of coexistence, and since statements are not interchangeable elements but groups characterised by their modality of existence' (Foucault 1972). The details of how Foucault envisaged 'statements' coming together into recognisable discourses across the enunciative field we do not have the space to go into here. They are laid out in bold outline in Philo (1989), wherein some recovery of discourse as a distinctive order of historical reality is argued, here the point of our current paper is somewhat more programmatic.

At this point it is worth making a further brief aside on conversation analysis (CA), which has emerged as one possible development of the work of Harvey Sacks. Critiques of CA's drift away from the early concerns of Harvey Sacks, and perhaps more tellingly of ethnomethodology, toward a scientistic and formalist approach have been made by Lynch \& Bogen (Bogen 1999; Lynch 1997). In a brief elucidation of the difference between the corpus of materials used by CA practitioners and the archive as used by Foucauldian scholars, McHoul \& Grace (1995) put it thus: 'Foucault's archive is not just a collection of texts or materials ... but the form of organisation of the parts of a discourse (its statements) ... Classically, CA's version of discourse looks for techniques of saying how turns are taken in conversations, for example. By contrast, Foucault's discourse theory looks for techniques of 'what can be said' pp30-31. In Lynch's $(1993 ; 2001 ; 1996)$ recommendations as to how Sack's diverse collection of lectures might to be read and re- 
used by those not wishing to pursue 'classical CA' he pushes back toward the second movement in most of Sack's (1992a; 1992b) lectures. This second reflective movement was toward examining a conversational fragment's relation to what can be described, what can be offered as a possible story in and about the world and lead thus to question the very possibilities of telling, knowing, describing, seeing and doing analysis at all.

The position outlined above could not be further removed from a focus on the universal, Humean laws and rules sought by many conventional social scientists, or indeed from a focus on the systematic and structural regularities sought by structuralists at the expense of how such regularities were (for Foucault) and are (for ethnomethdologists) made / produced / assembled. Against the promises of explanation from history or sociology it aligns Foucault's argument that 'archaeology is a purely descriptive enterprise' (Foucault 1977) with ethnomethodology's insistently descriptive approach to language (Lynch 1993; p199). There is no need from either position to build a second order Discourse to comprehend discourses, nor Meta-theory of theories. Instead there is a requirement to supply actual historical and social statements/activities that explode the essentialised meanings of power, know, reason, and so on, which develop into, as Lynch (1993) concludes, 'hypostatized concepts such as Knowledge, Representation, Reason and Truth.' This move toward situated, local, practical productions of, say, reasoning, or searching for the truth, does not entail any kind of scepticism or, worse, despair about truth or reason, 'nothing could be further from the case. If an investigation attends to how an expression (for example, a 'statement' in Foucault or a 'usage' in Garfinkel) comes to be counted as true, historically or situationally, this does not mean the investigator is skeptical of that expression's status as true once it has been so counted' (McHoul 1996) p105.

Where Foucault's attention alighted upon the problem of documents and discourses he claimed that that ' $[\mathrm{t}] \mathrm{he}$ question proper to such an analysis might be formulated in this way: what is this specific existence that emerges from what is said and nowhere else' (Foucault 1972, p28). More precisely, the researcher must ask, 'how is it that one particular statement appeared rather than another?' (Foucault 1972 p27). Foucault thus sets himself the task of chipping away at the limits partitioning off what is said at a particular time and place from what is not said. In a very real sense, he had previously been concerned with the investigation of these limits, but it was only in the Archaeology of Knowledge that he first seriously set about codifying his position explicitly, and first set about demonstrating - albeit in 'the cautious stumbling manner of this text' (Foucault 1972, p17) - just how this position could be translated into a methodology. The outcome was, by his own admission, 'a whole apparatus whose sheer weight, and, no doubt, somewhat bizarre machinery are a source of embarassment' (Foucault 1972 p135). We would argue that is not necessary to pursue Foucault into the heart of this 'bizarre machinery', since one can easily be a competent and sensitive archeologist without ladening one's analyses with the pewildering profusion of notions and terms that comprise this precarious edifice ${ }^{4}$. The richly textured pages of 'Madness and Civilisation'

\footnotetext{
${ }^{4}$ Once again for reasons of space we can only footnote here the striking similarity here of the uses of 'machinery' in Harvey Sack's (1992a,b) lectures, and the recommendations of ethnomethodologists to beware of being drawn too deeply into giving technical names to what any competent speaker can do.
} 
(Foucault 1988 (1961)), 'The Birth of the Clinic' and the 'Order of Things' readily attest to this fact since these texts clearly display Foucault's archaeology at work, even though most of the notions and terms of the Archaeology of Knowledge are not immediately present. Moreover, we believe that archaeology is more of a style, a set of commitments to what is right there before you in its ground, than it is a starkly laid out and unequivocal manual of research procedures.

... in Foucault as well as Garfinkel there is a common method, and this means not 'accepting' social facts that must be explained after the fact; rather it means, in Garfinkel's phrase, catching 'the work of fact production in flight,' ... Passages from Garfinkel's Studies on the accomplishment of social facts appear uncannily parallel to Foucault's treatment of the construction of truth(s) ... Both writers find their topics in the relation between work (activities) and conditions of possibility (available methods) that, in quite local circumstances, lead to certain accounts being heard and accepted as 'true' or as 'the facts,' where this analytic method contrasts with those that try to adjudicate between different account's veridicality (for example, theories of 'ideology'). (McHoul 1996) p104

There is a kind of existential priority running through Foucault's work and those of ethnomethodologists which constantly turns them toward studying what exists. This in no way minimises the access to the problem of social order since social order is taken to be at work at all points, particular practical solutions being produced everywhere and at all times. What is important is to assemble a corpus. From a properly assembled corpus an investigator acquires not just, say 'data', but how such 'data' is possible. As Deleuze argues it '... once the corpus has been established (which does not in any sense impose limits on the statement) we can then determine the way in which language [langage] gathers round or 'falls' into this corpus' ' (Deleuze 1988a) p18. By way of contrast, structuralism studied systems which gave numerous possibilities and some impossibilities. If an impossibility for the system was found to exist then the system had to be pulled to pieces and re-assembled to be able to contain this possibility too.

\section{Describing appearances / the depths of surfaces}

Methodologically, then, it seems very difficult to stick to what is actually stated, to nothing but the actual inscription of what is said. Even (and above all) linguistics does not remain content with that, especially when its classifications are on a different level from what is said. (Deleuze 1988a) p15

Where there are some of the most striking harmonies between Foucault's approach to examining the traces of history and ethnomethodology's orientation to explicating 'seen but unnoticed' features of the present day is in their firm resolve to face up to what is grossly, obviously available. As Deleuze hints above on the challenge of staying with what you have in hand, and several pages earlier in his the quote about examining the workings of 'the curtain', there is no need to set off on a search for the Wizard of Oz for 
Foucault's or for Garfinkel's studies. Both approaches turn first to the techniques, technologies, practices, methods, statements and so on, that may later allow for characters/agents/subjects to appear as either mighty rulers, pathetic small men pulling levers or 'sincere liars' (as Lynch and Bogen (1996) call Ollie North). There is, if you will pardon the mild paradox, a deep concern with the surfaces of the world. As Lynch and Bogen express it, on the surface of the text:

'In view of the fact that so much social-scientific, literary and philosophical effort has been devoted to getting to the bottom of discourse, our aim of sticking to the surface of the text may strike some readers as curious. It is our view, however, that any deeper readings would have to ignore the complexity and texture of the surface events, and thus they would fail to explicate how an order of activities is achieved as a contingent, moment-by-moment production' (Lynch 1996)

Neither Foucault nor ethnomethodologists use the 'unsaid' or the 'subconscious' or 'total history' or other devices that usher in invisible explanations of order. Relentlessly, even tediously, they are concerned with the order that is made available and is everywhere to be examined. There is nothing hidden although there are things that we are urged to take notice of, things that we have come to ignore through excessive familiarity with them in the archive/through witnessing, doing them and hearing them again and again on a daily basis. Both then are concerned with things lying in plain view, open to everyone and yet unexamined. Targets for Foucault's displays of, for instance, discipline-in-action (Foucault 1977) are hermeneutic and structuralist studies which probe into the murky depths of the 'unsaid'; the former searching for unexplained meanings, understandings and intentions locked in individual and group psyches, and the latter searching for the impersonal rules that determine how possible and actual parts of the documents interrogated combine together. Foucault's analysis renders structuralist and depth explanations 'invisible' because he shows how events had to be put in place so that something like an 'inner psyche' became a historical possibility. Ethnomethodology has, along similar lines, dissolved questions of social order that pre-defined hidden superstructures to which only analysts apparently have privileged access, and they have also targeted varieties of psychology which seek explanations of reason and conduct in an only indirectly accessible inner mental/cognitive realm (Coulter 1983; Coulter 1999).

Following from his distancings from hermeneutic and structuralist studies, Foucault hunts in the Archaeology of Knowledge, for a completely new approach to the problem of how to disinter some 'reality' from the stubborn existence of documents. He stresses the need to treat documents seriously on their own terms and he signposts this treatment as an 'archaeological excavation of documents as monuments : '[t]he document, then, is no longer for history an inert material through which it tries to reconstitute what men (sic.) have done or said, the events of which only the trace remains; history is trying to define within the documentary material itself unities, totalities, reveries, relations' (Foucault 1972, p7). There is no attempt to read beneath the document since he supposes that the document itself reveals at least as much - if not more - information about the 'reality' of the human agency and social practices involved in its formation as can positivistic, hermeneutic, or structuralist inquiries. Furthermore, Foucault's archaeology by staying 
much closer to the document, is less prone to the blindnesses exhibited by, and the distortions smuggled in by, other approaches as they endeavour to peer beneath the delicate surface specificity of the documents

Once again there are important parallels in the manner in which ethnomethodology takes seriously the grossly accessible features of the world which its researchers inhabit. Whilst other social sciences operate as if they were archaeologists in another sense, 'reconstructing the society from its fragments and leftovers, for example, by analysing the contents of little used files collected by the many administrative organisations present in our society or pouring over tables of correlations' (Sharrock \& Hughes 2001) ethnoinquries face up to the surplus of detail provided by actual events at hand. Yet this willingness to start investigations where the 'researcher is at', without using the highly technical and sophisticated methodologies which promise general explanations and models of larger social structures, leads to several misunderstandings. As Lynch and Bogen put it:

Ethnomethdology's orientation to singular details is often misunderstood as an epistemological perspective that credits the existence of local, micro or immediately visible events and actions, while denying the existence of larger, or more abstract, social and cultural phenomena (e.g. Power, the state, demographic trends, structures of inequality, systems of meaning etc.) Such thinking mistakes an investigative orientation to a phenomenal field - held to be real, intelligible, studiable and largely unstudied in the human sciences- with a metaphysical stance to the effect that anything beyond the limits of that field is a doubtful construction. Such a view is belied by the overt and repeated insistence by ethnomethodologists that ordinary language concepts and commonsense knowledge for most part are not lesser forms of knowledge requiring scientific validation. Vernacular conceptions of power, knowledge, meaning, historical context and so forth, are ubiquitous.' From (Lynch 1996) 'The Spectacle of History', p272

Interestingly Foucault's work, by comparison, even though concerned with the minutiae of discipline, sexual practice or medical vision, has never been taken to be a microhistory. It has been ethnomethodology in its preference for the everyday, mundane and blindingly obvious over the metaphysical, transcendental or invisible that has almost always taken to be a form of micro-sociology which really ought to be paired up with appropriate macro-sociologies to warrant any grander claims about society. Yet this would possibly be the worst combination possible since it is nearly always macrosociologies to which ethnomethodology stands in radical disjuncture. What we envisage here as a shared commitment in these two different inquiries is a concern for the minute, for the local details as, not subordinate to, but levelled with social order, with rules and regimes.

\footnotetext{
${ }^{5}$ Although Foucault is at times quite scathing about such endeavours, it should be noted that his advocacy 'is not a way of saying that everyone else is wrong ... [it is not] trying to reduce others to silence, by damning what they say as worthless' (Foucault 1972 p17). His commitment is what Thrift (Thrift 1996; Thrift 2000) would describe as 'modest theory'.
} 
Neither Foucault nor ethno-inquiries use a priori definitions of power or order and then inspect the world to see if they can find their stipulated form of power there, and this has several consequences, some of which we will deal with here and some of which we will return to later. They start with the materials they have at hand and take those materials seriously for their part in the production of social order.

In both Foucault and ethnomethodology, it is possible to locate an abiding common concern with the local production of institutional orders, even if ethnomethodology is more consciously 'analytic,' preferring to 'say' how socio-logical problems and their practical solutions work rather than to 'show' how they might, as possibilities. In this respect Foucault refers to 'eventalisation' (as opposed to generalization), whereas Garfinkel prefers to think of 'invariance' (Discourse) as a function or effect of contingency (discourse). Both, however, reject the idea that social practice is merely an effect of structurally given forms or ideal-rational rules behind the surface of visible action.' (McHoul 1996) pp103-104

The two approaches pursue cases where surface appearances are problematised but not by the theorist, rather by certain persons, groups, places (see Lemert \& Gillan 1982 'strange beginnings', 'exceptional cases'). For Garfinkel (1967) Agnes as a candidate trans-sexual passing as a woman, for Sacks (1972) the police looking at the streets without trust in appearances. For Foucault - history provides for juxtapositions - the body of the condemned versus the confessional. In a sense then both approaches rely not on a superbly clever abstract theorist thinking by themselves but rather on finding an often marginalised or specialised group for whom what has become taken for granted and unproblematic by most of us cannot be so for them. They then consult those people as serious experts in producing, say, mental illness or gender in the face of embodied, situational and practical difficulties. They do not treat these grounded experts' accounts and experiences and documentation as mistaken or ideological, but rather as making certain (seemingly theoretical) problems particularly clear. By learning from those who deal with 'theoretical' problems as practical matters, perspicuous studies are provided for the purposes of vanquishing theory-driven sociologies/histories. In neither Foucault's inquiries nor ethnomethodology's studies do we then encounter a garden-variety empiricism which has never engaged with conceptual / grammatical / theoretical investigations. It is perhaps, though we would be wary of ushering all the troubles in that go with such a term, a kind of existential resolution to questions of possibility posed by theorists. A resolution which leaves the theorists, so often in a hurry to pose yet more questions waiting around to find out if their initial questions were questions worth asking.

\section{Investigations must be done}

So 'what next?' How are we going to start our next study? Almost certainly we will begin without trying to define one of the mighty topics of critical inquiry such as 'power' or 
'reason' or 'justice' or 'community'. Turning to Lynch and Bogen again, (1996) p273 but this time on not being a priori:

"We are not proposing an inquiry free of presuppositions; instead, we are disclaiming that our inquiry is theory-laden in the sense of being framed by a professionally fashioned nexus of definitions, propositions, and a priori expectancies. The promise of such an approach is to gain a more differentiated appreciation of the phenomena in question (and of their situated uses and fates) than we would gain if we were to address them as "concepts on holiday." This sort of inquiry is not intended to satisfy certain popular academic demands for explanations, critiques of power, and systematic theories, and we doubt that many of our colleagues in the human sciences would want to follow the sort of path we have taken."

Foucault, as we have noted above, refused definitions of power as any kind of step toward revealing what power consists of and in what historical forms if was exercised. Even a small claim by a historian required the lengthy uncovering of its detailed architectures. Equally Sacks's comments were that a definition of something as typically done in the social sciences was akin to erecting a headstone over a grave. Aside from burying the phenomenon, it in no way gave you the life that preceded the headstone's erection. Avoiding stipulative treatments of social and historical phenomena is a central tenet of both approaches. In our investigations we will find 'what next' by encountering it, becoming immersed in it, living a life together, in short 'becoming the phenomenon'. For us 'what next?' is not a call for definitions then, it is more like an invitation for something else to come along which we really do not yet know. Almost for us now an exclamation of surprise at what's happened so far and what could possibly happen next (as in 'whatever next!')

Garfinkel's founding text 'Studies in Ethnomethodology' can be a puzzling read for anyone hoping to gut the theoretical organs out of it. The book, likes its founder, does not appear to have a heart ${ }^{6}$. Flicking through the chapters, you search in vain for definitions of social organisation, sexuality or explanations of suicide statistics. Most readers at that point abandon it, weary of its lack of headlines, models, three point summaries or Big Idea. For those that go on and read the chapters, or numerous other papers by ethnomethodologists (Goodwin 1997; Harper 1998; Lynch 1993; Orr 1996; Pollner 1987; Raffel 1979; Sacks 1972; Sharrock \& Anderson 1994; Suchman 1987; Sudnow 1972), each seems to stand by itself, building to no greater picture. Ethnomethodology seems belligerently unwilling to offer the reader a position outside of the details of each empirically exhausting study; to offer a heart to pluck out. Equally one only has to browse through the pages of Foucault's major texts, including the Archaeology of Knowledge, to realise that these are the creations of an historian sensitive in the last instance to the startlingly diverse substantive details encountered in the play of the historical record. Notwithstanding the attacks of some uncharitable critics, it is patently obvious that Foucault is far more interested in the colourful substantive nuances studding

\footnotetext{
${ }^{6}$ Using a phrase from Deleuze and Guattari (1988b) it would be appropriate to describe Garfinkel as a 'body without organs', and we mean this positively, if a little humourously.
} 
the histories of madness, medical perception, the human sciences, carceral practices and sexuality than he is in producing the colourless and generalised notations of formal language systems. This state of affairs in Foucault's project and ethnomethodology's corpus is closely bound up with their complicated, if not to say, tense relation with theory.

As Alan Sheridan declares; 'Foucault does not have a theory of history, which he then sets about 'proving'. The mass of detailed analysis he brings to bear in his work is not material to support a theory, in the sense that this analysis would be 'invalidated' if the theory were proved 'false ... For Foucault, theory does not enjoy the same status as detailed analysis, to which it is secondary, subservient.' Harvey Sacks in his lectures on conversation (1992a,b) and Garfinkel (1964) in his breaching experiments constantly pushed their students toward doing practical exercises as 'apprenticeships' in analysis (see Lynch 1999), whenever they could they steered them away from abstract theory.

Where Thrift has used dance to try and give a sense of where his non-representational project might lead us next, Harvey Sacks mentioned poetry as analogous to studies understood as non-generalisable, without existing classification into a discipline and unacceptable in a paraphrased form.

"The upshot of what I've said is this: I make no commitment to what kind of placing anyone makes of what it is that I do, nor to whatever recommendations anyone might provide me, which turn on such a treatment. Now that will be very hard to accept, except under one condition: If I said I was maybe doing poetry, then, that one doesn't want to accept somebody's paraphrase, that one doesn't want to treat the various classifications that are available as locating it, as fully dealing with it and equivalent to it, is acceptable under perfectly conventional views of what poetry does. For example, Paul Valery, in his book on the art of poetry, gives a characterization of it which roughly is: You have a poem when nothing that's a paraphrase is equivalent to it; when you have to go back to the poem to find out what's in it.' Harvey Sacks, p621 'General Introduction' (to his lecture course)

It is a simple point, and we have said it before several times ourselves, to see what Foucault is really doing, or Garfinkel and Sacks, you have to go back to their writings to see what are in them; you have to try do as they have done. They did not particularly want their work to be cited, they wanted to show how imaginative, insightful and surprising investigations could be done. It is a double imperative from both approaches not just to be faithful to sources in your reading but to be faithful in your studies to the places, events, occasions out of which they emerged. Never settling easily into the French or US university systems of teaching and researching, Foucault and Garfinkel kept doing their long, detailed empirical studies without which their other more programmatic claims were unwarranted. The commitment to painstaking investigations of this or that was directed to more than warranting grand claims about order, organisation, social facts. It was more than re-specifying inappropriately formulated problems of theory. To repeat ourselves: theirs was a practical demonstration of how research might and could be done; they were not exhibiting ideas, they were and are showing us how to think with the 
materials we can find in archives and in motion all around us. They show commitments in each and every case to a messy, ugly, bright and beautiful world of creatures great and small.

The 'what next' for us remains imperative and declarative: we must do social and historical investigations with already raised, blindingly obvious, sometimes strange and promisingly undefined subjects. 


\section{Bibliography}

Bogen, D. 1999: Order without rules: critical theory and the logic of conversation. State University of New York Press, New York.

Coulter, J. 1983: Rethinking Cognitive Theory. Macmillan, London.

-. 1999: Discourse and Mind. Human Studies 22, 163-181.

Deleuze, G. 1988a: foucault. Athlone Press, London.

Deleuze, G., \& Guattari, F. 1988b: A Thousand Plateaus. Capitalism and Schizophrenia Volume 2. Athlone Press, London.

Foucault, M. 1971: Nietzsche, la généalogie, l'histoire. In: Hommage à Jean Hippolyte. PUF, Paris.

-. 1972: The Archaeology of Knowledge. Tavistock, London.

-. 1977: Discipline and Punish : The Birth of the Prison. Allen Lane, London.

-. 1988 (1961): Madness and Civilization: A History of Insanity in the Age of Reason. Vintage Books, New York.

Garfinkel, H. 1964: Studies of the Routine Grounds of Everyday Activities. Social Problems 11, 1-33.

-. 1967: Studies in Ethnomethodology. Prentice-Hall, Englewood Cliffs, NJ.

-. 1974: The Origins of the Term 'Ethnomethodology'. In: Ethnomethodology (Turner, R. ed). Penguin, London. pp. 13-18.

Garfinkel, H. \& Sacks, H. 1970: On Formal Structures of Practical Actions. In: Theoretical Sociology: Perspectives and Developments (McKinney, J. C. \& Tiryakian, E. A. eds). Appleton-Century-Crofts, New York. pp. 337-366.

Garfinkel, H. \& Wieder, D. L. 1992: Two Incommensurable, Asymmetrically Alternate Technologies of Social Analysis. In: Text in Context: Contributions to Ethnomethodology (Watson, G. \& Seiler, R. M. eds). Sage, London. pp. 175-206.

Goodwin, M. 1997: Transparent vision. In: Interaction and Grammar (Ochs, E., Schegloff, E. A. \& Thompson, S. A. eds). Cambridge University Press, Cambridge.

Habermas, J. 1980: Moral Consciousness and Communicative Action. MIT Press, Cambridge.

Hacker, P. M. S. 1989: Insight and Illusion, Themes in the Philosophy of Wittgenstein (Revised Edition). Thoemmes Press, Bristol.

-. 2000: Was he trying to whistle it? In: The New Wittgenstein (Read, R. \& Crary, A. eds). Routledge, London. pp. 353-388.

Harper, R. 1998: Inside the IMF, An Ethnography of Documents, Technology and Organisational Action. Academic Press, London.

Laurier, E. \& Philo, C. 1999: X-morphising: a review essay of Bruno Latour's 'Aramis or the love of technoloy'. Environment and Planning A 31, 1043-1071.

-. 2003: The region in the boot : mobilising lone subjects and multiple objects. Environment \& Planning : D, Society and Space.

Lemert, C. C. \& Gillan, G. 1982: Michel Foucault: Social Theory and Transgression. Columbia University Press, New York. 
Lynch, M. 1993: Scientific practice and ordinary action: ethnomethodology and social studies of science. Cambridge University Press, Cambridge.

-. 1997: The Ethnomethodological Foundations of Conversation Analysis. Paper pres. Ethnomethodology, an improbable sociology?, Cerisy-la-Salle, France.

-. 1999: Silence in Context: Ethnomethodology and Social Theory. Human Studies 22, 211-233.

-. 2001: Ethnomethodology and the logic of practice. In: The Practice Turn in Contemporary Theory (Schatzki, T. R., Knorr Cetina, K. \& Von Savigny, E. eds). Routledge, London. pp. 131-148.

Lynch, M., \& Bogen, D. 1996: The Spectacle of History: Speech, Text and Memory at the Iran-contra Hearings. Duke University Press, London.

McHoul, A. 1986: The Getting of Sexuality: Foucault, Garfinkel and the Analysis of Sexual Discourse. Theory, Culture \& Society 3, 65-80.

-. 1996: Semiotic Investigations : Towards an effective semiotics. University of Nebraska Press, London.

McHoul, A. \& Grace, W. 1995: A Foucault Primer: Discourse, power and the subject. UCL Press, London.

Megill, A. 1985: Prophets of Extremity : Nietzsche, Heidegger, Foucault, Derrida. University of California Press, Berkeley.

Orr, J. E. 1996: Talking About Machines: An ethnography of a Modern Job. Cornell University Press, London.

Philo, C. 1992: Foucault's Geography. Environment \& Planning : D, Society and Space 10, 137-161.

Pollner, M. 1987: Mundane Reason. Cambridge University Press, Cambridge UK.

Raffel, S. 1979: Matters of Fact. Routledge \& Kegan Paul, London.

Sacks, H. 1963: Sociological Description. Berkeley Journal of Science 8, 1-16.

-. 1972: Notes on Police Assessment of Moral Character. In: Studies in Social Interaction (Sudnow, D. ed). Free Press, Glencoe. pp. 280-93.

-. 1992a: Lectures on conversation, Vol. 1. Blackwell, Oxford.

-. 1992b: Lectures on Conversation, Vol. 2. Blackwell, Oxford.

Sharrock, W. \& Anderson, B. 1994: The user as a scenic feature of the design space. Design Studies 15, 5-18.

Sharrock, W. \& Hughes, J. A. 2001: ETHNOGRAPHY IN THE WORKPLACE: Remarks on its theoretical bases. Team Ethno 1, http://www.teamethnoonline.org/

Suchman, L. 1987: Plans and Situated Actions : The Problem of Human-Machine Communication. Cambridge University Press, Cambridge.

Sudnow, D. 1972: Temporal Parameters of Interpersonal Observation. In: Studies in Social Interaction (Sudnow, D. ed). Free Press, New York. pp. 259-279.

Thrift, N. 1996: Spatial Formations. Sage, London.

-. 2000: Afterwords. Environment and Planning D: Society and Space 18, 213-255.

Watson, R. 1992: The understanding of language use in everyday life: Is there a common ground. In: Text in Context: Contributions to ethnomethodology (Watson, G. \& Seiler, R. M. eds). Sage, London. pp. 1-19.

Wittgenstein, L. 1953: Philosophical investigations. Blackwell, Oxford.

-. 1961 (orig.1922): Tractatus Logico-Philosophicus. Routledge and Kegan Paul, London. 
-. 1980: Culture and Value. Blackwell, Oxford. 